\title{
Factors Affecting Career Selection of Social Sciences Students
}

\author{
* Dr. Fouzia Ajmal, Assistant Professor (Corresponding Author) \\ ** Mah-e-Seemi, Scholar \\ *** Alina Raza, Teaching/Research Associate
}

\begin{abstract}
Career selection is about the career choice of an individual which should be according to the skills and aptitude of that individual in combination with his/her interests. This research was conducted to show the involvement of parents, societal values as well as the results of lack of career guidance and counseling programs. It was carried out through a survey of BS students of the Faculty of Social Sciences. The research is significant for parents as well as teachers to guide the students towards the right path while choosing their career. The data depicted that force from parents in career selection of their child is very dominant. Besides, lack of career guidance and counseling programs result in difficulties for students. Students choose career either by inspirations or based on their aspirations. There are too many fields but lack of guidance and counseling leads students to follow either what their elders want them to, or to follow their inspirations and aspirations. Career counseling programs are recommended for the students at an early stage which is very necessary and becoming the demand of the society as there are too many emerging fields.
\end{abstract}

Keywords: $\quad$ Career Selection, Students, Guidance, Pakistan

Introduction

Career selection is the most important thing about which the parents of children are mostly worried about right after the time of their birth. The selection of a career is not a simple procedure. Guidance is needed for the right and suitable selection of careers of children. The study will help in finding out the right time of career selection and what one must know while selecting his/her career. Even though every individual possesses different skills; our system, schools, and parents' forces on some common careers to be chosen by the children.

According to Oxford English Dictionary, career is defined as "a person's course or progress through life or a distinct portion of life". In this definition, a career is understood to relate to a range of aspects of an individual's life, learning, and work. Career is also frequently understood to relate to the working aspects of an individual's life. A third way in which the term career is used is to describe an occupation or a profession that usually involves special training or formal education and is a person's lifework. Career selection refers to the choice of the career based on personality traits that lead a person towards the career of a given type (Brown, 2002). Career development is the total and combined development of psychological, economic, social, physical, and educational and chance factors to form the career of an individual ( Eliason, 2008). Career counseling deals with the process of combined counseling of career development and career selection over the lifetime of an individual (Zunker, 2011). Career counseling programs are held in the schools to provide clear guidelines to students about their acquired needed information, skills, and aptitudes that will enhance all dimensions of their needs (i.e. social, personal, emotional, physical, and career) (Worzbyt, O'Rourke, \& Dandeneau, 2003).

\section{Historical Background of Career Counseling}

Before the $20^{\text {th }}$ century, there was no concept of career choice so no concept of career counseling. In most of the areas, youngsters did what their parents do. Young boys adopted the profession of their fathers like farming and carpentry. Same as the case with young girls; they went on their mothers'

\footnotetext{
* Department of Education, International Islamic University Islamabad Email: fouzia.ajmal@iiu.edu.pk

** Department of Education, International Islamic University Islamabad

*** Department of Education, International Islamic University Islamabad
} 
footprints and worked at home or the farms. But due to the industrial revolution in the $20^{\text {th }}$ century, so many new fields were introduced. Slowly and gradually, to work along with a comprehensive and systematic approach, it became necessary that students come to the newly introduced fields and they had to leave their family profession for that purpose (Yu-Chuan, 2019).

As a result, the Comprehensive Career Guidance System (CCGs) was introduced in the American Institute for Research. During the last decades of the $20^{\text {th }}$ century and the start of the $21^{\text {st }}$ century, the importance of career guidance and counseling has been realized so work had been started for its implementation and development in the educational setting (Athanasou \& Esbroeck, 2008). In the early 1970s, career guidance and counseling programs were established in the schools at the primary to secondary level which consisted of children from 5 to 18 years (Rullo, Eliason \& Patrick, 2008). But in our society, even now there is no concept of career guidance and counseling programs at all school levels.

\section{Theories of Career Selection}

\section{Holland's Theory of Career Choice}

Holland's theory of career choice explained that there are six personality types and six types of environment. So, people who choose the best environment according to their personality type are more satisfied and successful in comparison to those who choose the working environment and career not much related to their personality type.

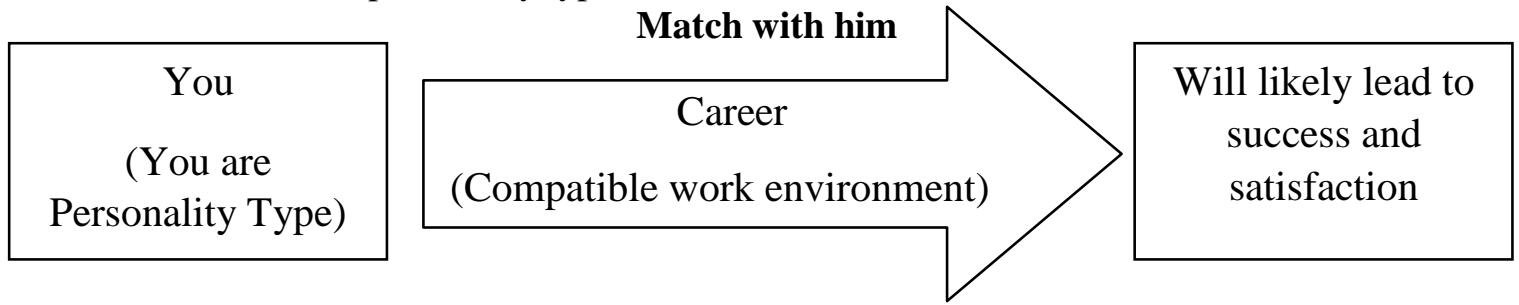

\section{Social Learning Theory of Career Choice}

According to Zunker (1990), there are four factors on which career development is based and these are:

a. Genetic endowment and special abilities

b. Environmental conditions and events

c. Learning experience

d. Task approach skills

\section{Gelatt's Decision Making Theory}

Gelatt's decision-making theory is based on the point that every individual has some options and he/she must choose the best from these options. To choose something from the available options, the best decision can be taken by going through the four-step decision-making process.

a. Step one: To make an individual realize that he/she must decide.

b. Step two: The person must search all the possible options and try to collect the information related to it so that he/she have some alternatives.

c. Step three: After searching through the alternatives, the person then tries to discover what will be the possible outcome of each option and then match and compare the option with his/her abilities and goals.

d. Step four: Then the person selects the best suitable option according to his/her values, goals, abilities, and personality.

e. The final step is to evaluate what the person chose and then make the final decision.

Career development is a lengthy and lifelong process. It is not just to choose a career in the early stages of life but to maintain that career throughout life (Brown, 2002). So, selecting a career randomly can lead to the situation that the selected career could be changed time after time. Therefore, it is necessary to select a career with the help of guidance and counseling so that leads the individual towards a successful career by developing within that career; not by changing the career frequently.

Career development is a lifelong process as it starts in childhood. The decisions about the career of elementary-aged students are likely by the effects of their studies, adults' experiences, and fields (Trusty, Niles, \& Carney, 2005). According to American School Counselor Association, if 
children are making career choices at the elementary level or they fail to make a career choice, then there is a need for career counselors to be involved in both the situations in helping and assisting the students in the process of career selection (Augar, Blackhurst, \& Wahl, 2005).

\section{Factors Affecting Career Selection}

There are so many factors that influence career choice and these factors are psycho-social emotional, individual, socioeconomic, societal, familial, and situational. The individual factor contains the abilities, aptitudes, and self-expectancies which affect substantially on career decisions. Family factor plays a key role in setting educational aspirations and occupational goals. While thinking about the field of study regarding the opportunities for job and employment, societal and socioeconomic factors affect. Thus the students who are well aware of these factors and how these affect, choose that field of study in which they would have alternatives in career choice (Newman \& Newman, 2009). So, for a clear understanding of students, there is a need to provide career awareness by arranging career guidance and counseling programs.

There are too many fields but due to lack of knowledge and guidance about them, students do not select these. With the absence of the facility of career guidance and counseling, students have no choice but to rely on what their parents and elders suggest them (Wasif, 2010). Many students follow someone who inspired them so they choose a career by inspiration, not knowing that it would not be of their type; that they have their personality so they would have different skills to which the inspired career would not be suitable. If we talk about young students; their parents want to select their careers related to their field and career. Choices are not provided to students. All they have provided with are common careers like doctors, teachers and engineers etc. or the same occupation as that of their parents (Brown, 2002). Children are usually seen to follow the career of their parents. The sons choose their fathers' occupations and that becomes their family occupation. Then it becomes compulsory for everyone in the family to choose the career and subject field related to their ancestors' field by focusing on the point that it could be hereditary; not realizing that individual differences occur and that one have different skills so he/she has to choose his/her according to skills and interests (Porter and Umbach, 2006).

\section{Importance of Career Counseling}

Career counseling is very much important for the students of junior and elementary level because that is the time to trace out the skills of the students by observing what are their interests, priorities, and preferences. But to know about the available careers, one must also be aware of his/her capabilities. So, career guidance and counseling are very much important for the students as it helps them getting knowledge about themselves. Career information and guidance helps in providing the knowledge about children's aptitudes and interests (Linden, 2003). According to Linden, guidance and counseling can perform a valuable role by making students aware of the opportunities and supporting them in securing entry to such opportunities. Such services promote individual liberty and choice and emphasize the active individual.

When students are at that age that they are sensible to manage their learning and they think of themselves as responsible enough for selecting their career then it is necessary to provide them information about their selves, their environment, and the society in which they live. The students should also be aware of the economic needs of their country as well as they should have provided information about the country's needs regarding different fields and professions. So, all this information is given to any student only through career guidance and counseling programs. Career guidance services help provide the link between all kinds of information with the aptitude and interests of the students. Career guidance promotes lifelong learning. Career guidance programs promote social equality as well as provides opportunities and guide students towards selecting the best suitable career (Linden, 2003). This all can get by choosing the right field of study according to the chosen career.

Career guidance plays its role in individual liberty and career choice and it emphasizes on active individuals. The dropout rate of students can be decreased by career counseling and mismatch of individual with its field of study and future profession can also be reduced (Rullo, Eliason \& Patrick, 2008). 


\section{Children's Preferences}

The selection for the right career of children can be traced by their preferences early in their lives. Magnuson and Starr (2000) discussed in their research that children show their preferences too early; first for food, toys, and games and then for clothing and then even while making friends. They have streamlined that the children show their tendency in becoming the professionals they want to be, very early in their lives. However, this article lacks any practical approach and suggestions for teachers and parents.

Children show their preferences very early, these choices leave a short-term impact on their lives. And these short-term impacts unknowingly on child's personality which expose at the time of long-term choices. It is a reality and fact that children also take decisions early in lives so it's important to develop their skills (Magnuson \& Starr, 2000) so they can make the right decision. Also, they need guidance for life career planning as early as they show their preferences for study fields (i.e. at elementary level). If we facilitate students with choices and opportunities and guide them about what would be suitable for them according to their skills then it will be helpful for them to turn into a successful person and making them capable in all aspects of their lives.

It provides knowledge and information to the children about their selves, their environment, and different fields they also find out what are the opportunities for them. They explore different career fields and then the awareness about every filed helps them choose the right career for them. School-level students are very much interested in what the adults do and how they do everything. They are also very much interested in adults' jobs, services, and professions. That is the right time to make them realize that the world of work is related to the academic skills and field of study (Magnuson \& Starr, 2000) so they have to choose the right field of study which is according to their skills, aptitude, and interest and at the same time leads them towards their ideal profession. (Autin, Duffy, Jacobson, Dosani, Barker \& Bott, 2018).

While selecting the career, the first and important step is to explore all the careers possible and suitable. Previous researches have been conducted about what children understand about the working life and to what extent (Hartung, Porfeli, \& Vondracek, 2005). In their article, they have reviewed the already available material in the field of career exploration. They have emphasized the value of career exploration and career awareness. According to the children should be given a proper chance to analyze and compare different professions socially, financially, and aptitude-wise. There are so many factors that make the image of an ideal career in the mind of students like family profession, trends, school environment, interests, values, and motivation. So it is important to involve the students in dynamic career exploration in which they explore different fields (Hartung, Porfeli, \& Vondracek, 2005) as well as their qualities, aptitudes, interests, and skills. The information and knowledge of the explored careers and personality characteristics of students together is helpful in the selection of the right career.

Research suggested that there should be career awareness programs for students at the school level. That is the time when they are coming out of the world of fantasy, so they need awareness. The students of late elementary level (i.e. $8^{\text {th }}$ graders) think and put their focus on all the factors which irritate them for example dissatisfaction, mismatches while comparing different fields with their abilities. The readiness to select their field of study exists in $8^{\text {th }}$ graders and it is necessary to provide career guidance at that level (Jones, 2020).

\section{Objectives of the Study}

The objectives of the study were:

1. To identify the extent to which students select their career by the choice of their parents.

2. To know the main factors that affect career selection of students

3. To show the deviation between the desired career and expected or chosen career of students.

\section{Significance of the Study}

The study is significant for parents about the career selection of their children. The study is also significant for teachers for guiding their students towards the right side when selecting their career.

\section{Delimitations of the Study}

The study was delimited to the students of the Faculty of Social Sciences at BS level at International Islamic University, Islamabad as the students at the university level have already selected their career so they could point out the factors which came as a hurdle while they were selecting their career. 


\section{Research Design}

The method adopted for the research study is descriptive. Descriptive research helps in describing what the researcher wants to find out about the study. A cross-sectional survey was conducted. The tool used for this research is a questionnaire which included open-ended as well as some close-ended questions.

\section{Sampling}

The sample of the study included 280 female students enrolled in the last semester of different departments at the Faculty of Social Sciences at International Islamic University Islamabad. The students were selected randomly.

\section{Instrumentation}

The questionnaire was chosen as a tool for the research. The questionnaire was self-designed and contained questions about career and the factors based on which students select their careers. The questionnaire comprised of both open-ended and close-ended questions and statements. The closedended questions and statements were also of two types; alternative type (i.e. yes/no) and multiplechoice type (i.e. strongly agree, agree, neutral, disagree, and strongly disagree). The validity of the questionnaire was estimated by the experts in education and psychology.

\section{Data Analysis and Interpretation}

Table 1: Future Profession

\begin{tabular}{ll}
\hline Profession & Percentage \\
\hline Teacher/ Lecturer & 74.99 \\
Educationist & 5.26 \\
Counselor & 3.95 \\
Admin & 3.95 \\
NGO worker & 3.95 \\
Writer & 2.63 \\
Newscaster & 1.32 \\
CSP officer & 1.32 \\
Do not know & 2.63 \\
\hline
\end{tabular}

As it is clear from Table 1, the future profession of most of the students will be teaching or lectureship. Almost three fourth of the students answered teaching or lectureship as their future profession and it makes almost $75 \%$ of the total sample of students. From the rest of the $25 \%$ of students, almost $22 \%$ answered differently as educationists, counselors, administration workers, NGO workers, writers, newscaster, and CSP officer. The rest of the 2 students answered that even at this higher level, they do not know about what their future profession will be.

Table 2: Level for Career Guidance

\begin{tabular}{ll}
\hline Level of education & Percentage \\
\hline Primary & 9.21 \\
Middle & 15.79 \\
Secondary & 47.37 \\
Higher secondary & 15.79 \\
University & 11.84 \\
\hline
\end{tabular}

While answering for the question of "on what level career guidance should be provided?" almost half the students (i.e. 47\%) from the sample answered that career guidance should be provided at the secondary level. An equal number of students i.e. $16 \%$ of the sample, answered for middle and higher secondary level, and a low number of students answered for primary and university level i.e. $9 \%$ and $12 \%$ respectively.

Table 3: Factors for Idealizing Field of Study

\begin{tabular}{ll}
\hline Factors & Percentage \\
\hline Interest & 32.89 \\
Inspired & 18.42 \\
Scope & 13.16 \\
Knowledge & 9.21 \\
Serve nation & 9.21 \\
Skills & 6.58 \\
Societal needs & 1.32 \\
Respect & 1.32 \\
\hline
\end{tabular}




\begin{tabular}{ll}
\hline Independence & 1.32 \\
Do not know & 6.58 \\
\hline
\end{tabular}

The above table shows the answers to the factors or reasons for the desired fields of studies. The most common factor that came out for idealizing a field of study is the factor of interest which got $33 \%$ of the answers. The second common factor that comes out was the field of the person to whom the respondent is inspired from and it contains almost $18.5 \%$ answers. The scope of the field is also a common reason for liking a field of study as it contains $13 \%$ of the answers. Then knowledge of the subject and passion for serving the nation got the same of 9.2\%. Almost $6.6 \%$ of the respondents replied matched "skills" and the least numbers of students wrote "societal needs", "respect in that field" and "independence" as the factor of idealizing a field and it is $1.3 \%$ each. The rest of the $6.7 \%$ of respondents did not know why they like a field of study.

Table 4: Factors for Changing the Career Choice

\begin{tabular}{ll}
\hline Factors & Percentage \\
\hline Parents & 25.00 \\
Societal values & 17.11 \\
Low marks & 13.16 \\
Health & 6.58 \\
Self-evaluation & 6.58 \\
Wrong guidance & 3.95 \\
Lost interest & 3.95 \\
Luck & 3.95 \\
Glamour & 1.32 \\
None & 18.42 \\
\hline
\end{tabular}

The above table shows the factors for selecting a different subject than the desired one and it contains 10 factors. The most common factor is parental influence due to which students chose different fields than they desired and $25 \%$ of the students wrote this factor. Then values in society are also a common factor for students to not select the subject which they want and $17 \%$ of respondents wrote this. Low marks in subject made $13 \%$ of the students to change their field of study. Then health reasons and self-evaluation also forced students to change their field and it include $6.6 \%$ for each of these two factors. $12 \%$ of students change subject because of losing interest in the previous subject, wrong guidance, and luck and $1.3 \%$ change the subject due to glamour in other fields of study. Almost $18.4 \%$ of students respond that nothing forced them; they are having the same field which they desired.

Table 5: Inspired from Whom

\begin{tabular}{ll}
\hline Person & Percentage \\
\hline Father & 25.00 \\
Teacher & 18.42 \\
Mother & 13.16 \\
Friend & 6.58 \\
Sister & 5.26 \\
Brother & 5.26 \\
Uncle & 5.26 \\
Army officer & 3.95 \\
Cousin & 2.63 \\
Quaid-e-Azam & 1.32 \\
Maulana Tariq Jamil & 1.32 \\
Imran Khan & 1.32 \\
None & 10.53 \\
\hline
\end{tabular}

The table above describes the frequency and percentage of whom the respondent is inspired from. Most of the respondents are inspired by their father, teacher, and mother having 25\%, 18\%, and $13 \%$ respectively. Then $6.6 \%$ are inspired by friends and $5.3 \%$ are inspired by their uncles, brothers, and sisters, respectively. Almost $4 \%$ are inspired by the personality of army officers and $2.6 \%$ from their cousins. Three of the respondents mentioned the name of the personalities who inspired them, and those personalities are Quaid-e-Azam, Maulana Tariq Jamil, and Imran Khan. A good number of people that are $10.5 \%$ are not inspired by anyone. 
Table 6: Attended Career Counseling Program

\begin{tabular}{ll}
\hline \multicolumn{1}{c}{ Responses } & Percentage \\
\hline Yes & 27.63 \\
No & 72.37 \\
\hline
\end{tabular}

The table above depicts that how many of the total respondents ever attended any career counseling and guiding program. A minority of the sample students answered "yes", and these are $27.6 \%$ and the majority said that they never attended such programs, and these are $72.4 \%$.

Table 7: Have Needed Career Counseling

\begin{tabular}{ll}
\hline Responses & Percentage \\
\hline Yes & 67.11 \\
No & 32.89 \\
\hline
\end{tabular}

The above-mentioned table shows the frequency and percentage of how many of the respondents think that they needed career guidance. Most of the sample said that they needed career counseling programs and these students are $67 \%$ and the minority said that they did not need any and those are $33 \%$ almost.

Table 8: Any Idea about Own Skills

\begin{tabular}{ll}
\hline Responses & Percentage \\
\hline Yes & 85.53 \\
No & 14.47 \\
\hline
\end{tabular}

The above table represents that how many of the respondents have any idea about their skills. A huge part of the sample said that they know about their skills and only $14.5 \%$ replied with "no", for the answer to "do you have any idea about your skills?"

Table 9: Career Guidance Programs are Must

\begin{tabular}{ll}
\hline Responses & Percentage \\
\hline Yes & 89.47 \\
No & 10.53 \\
\hline
\end{tabular}

The above table describes that $89.5 \%$ of respondents think that career guidance programs are a must and only $10.5 \%$ of respondents said that "no" to this statement.

Table 10: Awareness about the Fields Suitable to one's Skills

\begin{tabular}{ll}
\hline Responses & Percentage \\
\hline Yes & 77.63 \\
No & 22.37 \\
\hline
\end{tabular}

The table above is about how many respondents are aware of the fields that are suitable to them according to their skills. For this, $77.6 \%$ of respondents said they know the fields suitable to them according to their skills and $22.4 \%$ of students said that they are not aware of the fields matched with their skills.

Table 11: Current Field is Different from Dreamed One

\begin{tabular}{ll}
\hline Responses & Percentage \\
\hline Yes & 72.37 \\
No & 27.63 \\
\hline
\end{tabular}

The table above represents the data of the respondents whether they have their dreamed career or not. So, according to the table, $72.4 \%$ of respondents have different careers from which they desired or dreamed and $27.6 \%$ of respondents are now having their desired and dreamed careers.

Table 12: Parents Choice is more important

\begin{tabular}{lc}
\hline Responses & Percentage \\
\hline Strongly agree (5) & 44.74 \\
Agree (4) & 32.89 \\
Neutral (3) & 6.58 \\
Disagree (2) & 6.58 \\
Strongly disagree (1) & 9.21 \\
\hline
\end{tabular}

The table is the presentation of the importance of parents' choice for the respondent while selecting her career. Most of the sample population strongly agreed (44.7\%) and agreed (32.3\%) that the choice of their parents is most important to them whether matched with their talents or not. A small number $(6.6 \%)$ of respondents were neutral as for them, it depends on the situation that to whom they should give importance to. Some students also disagreed (6.6\%) and strongly disagreed $(9.2 \%)$ with the statement because they have chosen the field of their own choice (or they wanted to). So if we allow 
the numbers to strongly agree, agree, neutral, disagree, and strongly disagree from 5 to 1 respectively, then the mean of this data is calculated to be 3.9 which represents that majority is on the side of agreeing with the statement.

Table 13: Prefer to go with Aspiration instead of Skills

\begin{tabular}{ll}
\hline Responses & Percentage \\
\hline Strongly agree (5) & 13.16 \\
Agree (4) & 35.53 \\
Neutral (3) & 21.05 \\
Disagree (2) & 15.79 \\
Strongly disagree (1) & 14.47 \\
\hline
\end{tabular}

The table above depicts that if the respondents have different skills related to their interests then they will probably select the one in which they have found interest rather than the one matching with their skills. Most of the students agreed with that with the percentage of $35.5 \%$ and some students agreed strongly with $13.2 \%$ almost. The number of students who answered "neutral", whether do not know what their decision will be in that kind of situation or depending on the situation, was also quite a bit as it got almost $21 \%$. But some students will go with their skills in any such situation, so they disagreed and strongly disagreed with the percentages of $15.8 \%$ and $14.5 \%$ respectively. The means value of this statement is 3.2 showing the direction of the pointer towards "agree" which means the majority do not care about their skills in front of their dreams and aspirations.

Table 14: Chose Career by Inspiring from Someone

\begin{tabular}{ll}
\hline Responses & Percentage \\
\hline Strongly agree (5) & 11.84 \\
Agree (4) & 38.16 \\
Neutral (3) & 10.53 \\
Disagree (2) & 31.58 \\
Strongly disagree (1) & 7.89 \\
\hline
\end{tabular}

This above-mentioned table reveals the data on the statement that the respondents have chosen her career field by inspiring from someone. The data of the above-stated table is almost equally dispersed on both sides of the table from strongly agreed to strongly disagree. The respondents chosen strongly agreed and agreed are $11.8 \%$ and $38.2 \%$ respectively and those who have chosen disagreed and strongly disagreed are $31.6 \%$ and $7.9 \%$ respectively. The rest of the $10.5 \%$ of respondents became neutral and this shows that they are inspired by someone, but they did not choose their field according to it.

\section{Conclusion}

By researching the need for career guidance and counseling programs at the elementary level, the researcher s found out that, these programs must be facilitated at the school level and the respondents of the questionnaire used as a tool of this research also agreed with that. Following are some concluding points of the research, based on the data and findings of the research:

1. Students need career guidance at the school level. Students can easily be inspired by anyone and choose the same field of study as that of the person from whom they inspired.

2. Parental influence is a major factor for students who did not select desired fields.

3. Values in society plays a major role in some career to be chosen by the students, whether they have skills or interest.

4. Some students do not know why they love or hate a subject, why they are in some career, and

\section{Discussion} even what their future profession will be.

It is important to involve the students in dynamic career exploration in which they explore different fields (Hartung, Porfeli, \& Vondracek, 2005) as well as their qualities, aptitudes, interests, and skills. The information and knowledge of the explored careers and personality characteristics of students together is helpful in the selection of the right career. The current study confirms these ideas. Research suggested that there should be career awareness programs for students at the school level (Jones, 2020). The same is recommended by the current study also.

\section{Recommendations}

1. Teachers may tell students about their hidden skills and talents and advise them to choose the career according to it. 
2. Teachers may develop interest in students in the subjects related to their skills, so they choose the career according to their interests as well as skills.

3. Parents may give the options of the career to their children related to their talents and skills, not what their profession is, because parental influence is necessary, and we cannot negotiate it. Also, children like to select what their parents what them to, especially daughters so parents may also give them space during career selection.

4. If parents desperately want their child to select the career of their choice, then they must also

\section{References} show them the way to how they use their skills in that field.

Athanasou, J. A., \& Esbroeck, R. V. (2008). International Handbook of Career Guidance. Sydney.

Augar, R. W., Blackhurst, A. E., \& Wahl, K. H. (2005). The Development of Elementary Aged Children's Career Aspirations and Expectations. Mankato.

Autin, K. L., Duffy, R. D., Jacobson, C. J., Dosani, K. M., Barker, D., \& Bott, E. M. (2018). Career development among undocumented immigrant young adults: A psychology of working perspective. Journal of Counseling Psychology, 65(5), 605.

Brown, D. (2002). Career Choice and Development. San Francisco: Jossey-Bass.

Rullo, W., Eliason, G. T., \& Patrick, J. (2008). The ASCA model and the educational trust. Career Development in the Schools, 1.

Eliason. (2008). Career Development in the Schools. United States of America: Information Age Publishing Inc.

Hartung, P. J., Porfeli, E. J., \& Vondracek, F. W. (2005). Child Vocational Development; A review and reconsideration. Journal of Vocational Behavior, 385-419.

Jones, M. E. (2020). Effects of an Anchored Career-Focused Curriculum on the Knowledge and Attitudes of At-Risk High School Students. Theses and Dissertations--Early Childhood, Special Education, and Rehabilitation Counseling. 85. https://uknowledge.uky.edu/edsrc_ etds $/ 85$

Linden, T. (2003). Lifelong Learning in the Global Knowledge Economy: Challenges for Developing Countries. Washington, D.C.: World Bank.

Magnuson, C. S., \& Starr, M. F. (2000). How Early is too Early to Begin Life Career Planning, The Importance of the Elementary School Years. Journal of Career Development, 89-101

Newman, B. M., \& Newman, P. R. (2009). Development through Life: A Psychosocial Approach. United States of America: Cengage Learning.

Porter, S.R. and P.D. Umbach. 2006. College major choice: An analysis of person-environment. Research in Higher Education. 47(4):429-449.

Trusty, J, S.G. Niles, and J.V. Carney. 2005. Education-career planning and middle school counselors. Professional School Counseling. 9(2):136-143

Wasif, S. (2010). Inadequate Career Counseling in Schools. Express Tribune.

Worzbyt, J. C., O'Rourke, K., \& Dandeneau, C. (2003). Elementary School Counseling: A commitment to Caring and Community Building. Newyork: Brunner-Routledge.

Yu-Chuan, C. (2019). Study of the Factors Affecting the Career Development of New-ImmigrantChildren University Students in Taiwan. International Journal of Higher Education, 8(6), 192-202.

Zunker, V. G. (2011). Career Counseling: A Holistic Approach. Cengage Learning. 